\title{
Correction to: Effect of multi-cycle freeze-thaw tests on the physico-mechanical and thermal properties of some highly porous natural stones
}

\author{
İbrahim Uğur ${ }^{1} \cdot$ Hilal Özer Toklu ${ }^{1}$
}

Published online: 29 July 2021

๑) Springer-Verlag GmbH Germany, part of Springer Nature 2021

Correction to: Bulletin of Engineering Geology and the Environment (2020) 79:255-267 https://doi.org/10.1007/s10064-019-01540-z

In this article the funding from Süleyman Demirel University Scientific Research Projects Management Unit (no. 3842-D2-14) was omitted. The correct Acknowledgement is as follows:

"This research was funded by TUBITAK-3001 "The Scientific \& Technological Research Council of Turkey”
(no.114M090) and "Süleyman Demirel University Scientific Research Projects Management Unit" (no. 3842-D2-14). I am grateful to the institutions for their valuable support and cooperation during fieldwork."

The original article can be found online at https://doi.org/10.1007/ s10064-019-01540-z.

İbrahim Uğur

ibrahimugur@sdu.edu.tr

1 Mining Engineering Department, Suleyman Demirel

University, 32260 Isparta, Turkey 